\title{
Foliar Application of Flavonoids (rutin) Regulates Phytoremediation Efficiency of Amaranthus Hypochondriacus by Altering the Permeability of Cell Membranes and Immobilizing Excess Cd in the Cell Wall
}

\section{Yuchen Kang}

Sichuan University - Wangjiang Campus: Sichuan University

Jiaxin Liu

Sichuan University - Wangjiang Campus: Sichuan University

\section{Li Yang}

Sichuan University - Wangjiang Campus: Sichuan University

$\mathrm{Na} \mathrm{Li}$

Sichuan University - Wangjiang Campus: Sichuan University

Yuhao Wang

Sichuan University - Wangjiang Campus: Sichuan University

Tianqi Ao

Sichuan University - Wangjiang Campus: Sichuan University

Wenqing Chen ( $\sim$ kogami97@126.com)

Sichuan University - Wangjiang Campus: Sichuan University

\section{Research Article}

Keywords: Amaranthus hypochondriacus, Phytoremediation, Cadmium, Subcellular distribution, Phytochelatins, Prediction model

Posted Date: November 9th, 2021

DOl: https://doi.org/10.21203/rs.3.rs-915884/v1

License: (c) (1) This work is licensed under a Creative Commons Attribution 4.0 International License. Read Full License

Version of Record: A version of this preprint was published at Journal of Hazardous Materials on November 1st, 2021. See the published version at https://doi.org/10.1016/j.jhazmat.2021.127875. 



\section{Foliar application of flavonoids (rutin) regulates}

2 phytoremediation efficiency of Amaranthus

3 hypochondriacus by altering the permeability of

4 cell membranes and immobilizing excess $\mathrm{Cd}$ in

5 the cell wall

6 Yuchen Kang a, Jiaxin Liu ${ }^{\text {a }}$, Li Yang ${ }^{\text {a }}, \mathrm{Na} \mathrm{Li}^{\text {a }}$, Yuhao Wang a, Tianqi Ao ${ }^{\text {b }}$,

7 Wenqing Chen ${ }^{\text {a, * }}$

$8{ }^{a}$ College of Architecture and Environment, Sichuan University, Chengdu 610065, China

$9{ }^{b}$ State Key Laboratory of Hydraulics and Mountain River Engineering, Sichuan University, Chengdu

10 610065, China

11 *Corresponding author. Postal address: No. 24, South section 1, 1st Ring Rd., Chengdu, Sichuan Province, 610065, China. E-mail: kogami97@126.com (Wenqing Chen) Tel: +8618512870064. Fax:

$028-85462120$

Yuchen Kang: E-mail: 474319419@qq.com

Jiaxin Liu: E-mail: sculiujx2020@163.com

Li Yang: E-mail: 1273167630@qq.com

Na Li: E-mail: 2576183476@qq.com

Yuhao Wang: E-mail: 928573033@qq.com 


\section{Abstract}

The gap between the current serious soil heavy metal (HM) contamination situation and the low efficiency of soil remediation has become one of the factors limiting economic development and human health. The aim of this study was to propose a method to improve the efficiency of phytoremediation by exogenous rutin application and to explain the potential mechanism. A series of rutin treatments were designed to evaluate the biomass, cadmium (Cd) accumulation and phytoremediation efficiency responses of Amaranthus hypochondriacus to different levels of rutin $(0.5,1.5$, and $5 \mathrm{ppm})$ under different $\mathrm{Cd}$ stress levels $(10,25,50$, and $100 \mathrm{ppm})$. The determination of cell membrane damage indicators, the subcellular distribution of $\mathrm{Cd}$ and the establishment of a predictive model for $\mathrm{Cd}$ accumulation were also carried out. The results showed a decline in cell membrane damage with rutin application, and more $\mathrm{Cd}$ ions were immobilized in the cell wall than in the vacuole, resulting in an increase in $\mathrm{Cd}$ tolerance in plants. The addition of rutin caused significant effects on the synthesis of glutathione (GSH), including the advancement of the conversion of GSH to phytochelatins (PCs). Among them, $\mathrm{PC}_{2}$ and $\mathrm{PC}_{3}$ in the leaves contributed the most to the high accumulation of $\mathrm{Cd}$ in Amaranthus hypochondriacus according to the prediction model. Overall, the phytoremediation efficiency and phytoextraction amount of Amaranthus hypochondriacus with foliar rutin application were improved significantly by $260 \%$ and $319 \%$, respectively. These findings can contribute to the further development of soil remediation in Cd-contaminated fields.

\section{Keywords}

Amaranthus hypochondriacus; Phytoremediation; Cadmium; Subcellular distribution; Phytochelatins; 
Prediction model

42 


\section{Declarations}

\section{Ethics approval and consent to participate}

$45 \quad$ Not applicable

\section{Consent for publication}

Not applicable

49

Availability of data and materials on reasonable request.

Code availability

Not applicable

Competing interests

The authors declare that they have no competing interests. 


\section{Authors' contributions}

65

66

67

68

69

70

71

72

73

74

All authors contributed to the study conception and design. Conceptualization: W C; Writing - review \& editing: T A; Supervision: N L; Formal analysis: L Y; Investigation: J L; Methodology: Y W;

Writing - original draft: Y K. All authors read and approved the final manuscript.

\section{Acknowledgments}

This work was supported by the Project of Major Science and Technology of Sichuan Province [grant number 2018SZDZX0028]. Thanks to workers for the construction of experimental sites and transportation of experimental soils and all the people who have helped with the completion of the manuscript. We are indebted to the company, American Journal Experts (U.S), for their help in English improvement of our manuscript 


\section{Introduction}

Currently, with the rapid development of cities and industries, soil heavy metal (HM) pollution has become a major problem affecting agricultural production, food safety, human health and environmental safety (Liu et al. 2020, Wang et al. 2021). Compared to traditional chemical and physical remediation methods, phytoremediation is considered to be the most promising, cost-effective and environmentally friendly method of soil decontamination (Liu et al. 2013, Qin et al. 2021). However, the shortcomings of the low remediation efficiency of this method have become the main constraint to its wider application. Improving phytoremediation efficiency can be achieved by hyperaccumulator screening or agronomic manipulation (Wei et al. 2010). Phytomanagement, including water and fertilizer management, is a specific strategy employed in phytoremediation ( $\mathrm{Li}$ et al. 2021). Phytochelatins (PCs) and their glutathione (GSH) precursors are thiol-rich peptides and critical in HM detoxification in plants and microorganisms (Jacquart et al. 2017). Thus, primary methodologies for the regulation of PCs synthesis were utilized to achieve a better efficiency of phytoremediation, including genetic engineering, photosynthesis regulation and metabolite regulation (Cao et al. 2014, Chaurasia et al. 2008, Yuan et al. 2015, Zayneb et al. 2017). Metabolite regulation by exogenous imposition of metabolites associated with PCs metabolism is of exploratory interest.

A number of studies have identified a link between HM stress and autologous flavonoid metabolism in plants. Flavonoids are considered defensive agents of plants against environmental stress and have a strong ability to scavenge 2,2-diphenyl-1-picrylhydrazyl (DPPH) radicals, reduce superoxide anion activity and reduce oxidative stress (Dong et al. 2021). In addition to being free radical scavengers, flavonoids play an important role in enhancing the tolerance of plants by chelating HM and reducing the 
mobility of metal ions according to their different molecular structures, thereby inhibiting lipid peroxidation reactions (Stingu et al. 2012). Our research on metabolic responses and correlations with PCs in Amaranthus hypochondriacus identified 12 metabolites, such as flavonoids, of rutin that were highly linearly correlated with PCs (Xie et al. 2019). Previously, studies have investigated the effect of exogenous rutin application, providing high protection for the cell membrane and reducing oxidative stress damage in animal and microbial cells (Gong et al. 2010, Singh et al. 2018, Wang et al. 2015). However, little research has focused on the effects of exogenous flavonoids (rutin) on plant stress resistance and determining the related mechanism.

At present, there are no reports on the combined remediation techniques of exogenously applied natural antioxidant flavonoids and plants. Amaranthus hypochondriacus is an annual herb with rapid growth, easy cultivation, good adaptability, and Cd hyperaccumulation (Xie et al. 2020). In this study, $A$. hypochondriacus was treated with gradient concentrations of rutin under different concentrations of $\mathrm{Cd}$ stress to investigate the dynamic changes in biomass growth, $\mathrm{Cd}$ content in various parts, and sulfhydryl compound content. The differences in $\mathrm{Cd}$ accumulation were investigated at the subcellular level, and the most critical PCs for altering subcellular $\mathrm{Cd}$ accumulation were explored by the establishment of a $\mathrm{Cd}$ concentration prediction model. The alleviation of cellular damage after rutin application was explored to confirm the mechanism by which rutin enhances cellular $\mathrm{Cd}$ tolerance. Studying the effect of the natural exogenous antioxidant rutin on the resistance of $\mathrm{Cd}$-enriched plants to $\mathrm{Cd}$ stress could provide insight for the development of novel phytoremediation techniques. 


\section{Materials and methods}

116

117

\subsection{Plant materials and growth conditions}

The experimental soil (total Cd: $0.21 \mathrm{mg} \cdot \mathrm{kg}^{-1}$, available $\mathrm{Cd}: 0.06 \mathrm{mg} \cdot \mathrm{kg}^{-1}, \mathrm{pH}=5.86$ ) was collected from the farmland of Mianzhu City, Sichuan Province, China. Cd treatment was carried out by uniformly injecting of $\mathrm{CdCl}_{2} \cdot 2.5 \mathrm{H}_{2} \mathrm{O}$ solutions into the soil of each pot to the designed soil Cd concentration of 10 , 25, 50, and $100 \mathrm{mg} \cdot \mathrm{kg}^{-1}$. Seedlings of A. hypochondriacus were transplanted into experimental pots (80 $\mathrm{cm} \times 40 \mathrm{~cm} \times 40 \mathrm{~cm}$ ) with $70 \mathrm{~kg}$ of soil after two weeks of soil equilibrium. Ten days after transplanting, seedlings were fertilized with $1.2 \mathrm{~g}$ of liquid urea per pot. Exogenous rutin was applied $5 \mathrm{~d}$ after $\mathrm{Cd}$ application during branching stage (the seedlings grew to $40 \mathrm{~cm}$ in height). The treatments of exogenous rutin under different $\mathrm{Cd}$ conditions were as follows: $\mathrm{R} 0,0 \mathrm{mg} \cdot \mathrm{mL}^{-1} ; \mathrm{R} 0.1,0.1 \mathrm{mg} \cdot \mathrm{mL}^{-1} ; \mathrm{R} 0.5,0.5$ $\mathrm{mg} \cdot \mathrm{mL}^{-1} ; \mathrm{R} 1.5,1.5 \mathrm{mg} \cdot \mathrm{mL}^{-1}$; and $\mathrm{R} 5,5 \mathrm{mg} \cdot \mathrm{mL}^{-1}$. The rutin solution was sprayed on leaf surfaces and leaf backs until dripping. Three plants were randomly collected under each treatment condition after $3 \mathrm{~d}$.

The plants were divided into three parts, namely, the roots, stems and leaves, for fresh and dried biomass measurement. For each condition, triplicate analyses were performed.

\subsection{Analysis of malondialdehyde, electrolyte leakage and cell vitality}

Malondialdehyde (MDA) was determined to be a biomarker of lipid peroxidation and was measured to investigate the impact of rutin on plant cell membranes. A $0.1 \mathrm{~g}$ fresh sample was homogenized in $5 \mathrm{~mL}$ of $5 \%$ trichloroacetic acid (TCA). The cell suspension was centrifuged at $3000 \mathrm{rpm}$ for $10 \mathrm{~min}$. Then, 2 $\mathrm{mL}$ of $0.67 \%$ thiobarbituric acid (TBA) was added to the $2 \mathrm{~mL}$ supernatant and kept in a $100{ }^{\circ} \mathrm{C}$ water bath for $30 \mathrm{~min}$. After cooling, the mixture was centrifuged again at $3000 \mathrm{rpm}$ for $10 \mathrm{~min}$. The absorbance 
of the supernatant was measured at $450 \mathrm{~nm}, 532 \mathrm{~nm}$, and $600 \mathrm{~nm}$.

The loss of cell membrane integrity in root, stem, and leaf tissues was estimated with electrolyte leakage (EL) assessed by a conductivity meter. A $1.0 \mathrm{~g}$ sample was transferred into $20 \mathrm{~mL}$ of deionized water and kept for $1 \mathrm{~h}$ at room temperature, and the conductivity of the solution was recorded as $\mathrm{E}_{0}$. Then, the mixture was kept in a $100{ }^{\circ} \mathrm{C}$ water bath for $15 \mathrm{~min}$, and the conductivity was marked as $\mathrm{E}_{1}$. EL (\%) was calculated by the ratio of $E_{0}$ to $E_{1}$.

Cell relative vitality (CRV) (same for cell death) was determined by using the Evans Blue method (Ghasemi et al. 2020). Plant samples were incubated for 20 min with $0.25 \%$ (W/V) Evans Blue and then washed extensively with deionized water to remove excess and unbound dye. The dyed sample was boiled in $2 \mathrm{~mL}$ of $1.5 \%$ (W/V) sodium dodecyl sulfate (SDS) for $10 \mathrm{~min}$. The absorbance of the supernatant at $600 \mathrm{~nm}$ was denoted $\mathrm{C}_{0}$. The absorbance of the supernatant heated at $100{ }^{\circ} \mathrm{C}$ for $10 \mathrm{~min}$ was set as $100 \%$ cell death $\left(\mathrm{C}_{100 \%}\right)$. CRV was calculated as follows:

$$
\mathrm{CRV}=\left(1-\frac{\mathrm{C}_{0}}{\mathrm{C}_{100 \%}}\right) \times 100 \%
$$

\subsection{Measurement of $\mathrm{Cd}$ content}

Dried plant samples were ground into powder by a grinding instrument. Then, $0.1 \mathrm{~g}$ samples from root, stem and leaf parts were placed in a polytetrafluoroethylene crucible. Each sample was soaked for one night in $10 \mathrm{~mL}$ of mixed acid $\left(\mathrm{HNO}_{3}: \mathrm{HClO}_{4}=9: 1\right)$. Then, the samples were digested on an electric hot plate until nearly dry. After brining the volume to $10 \mathrm{~mL}$ with $1 \% \mathrm{HNO}_{3}$ and filtration through a $0.45 \mu \mathrm{m}$ membrane filter, the samples were measured by inductively coupled plasma mass spectrometry. 
153

\subsection{Analysis of $\mathrm{Cd}$ subcellular distribution}

A frozen sample (approximately $0.5 \mathrm{~g}$ ) was homogenized by a plant grinder in $5 \mathrm{~mL}$ of precooled extraction buffer ( $50 \mathrm{mM}$ Tris-HCl, $250 \mathrm{mM}$ sucrose, $1 \mathrm{mM}$ mercaptoethanol, $\mathrm{pH}$ 7.5). The homogenate was separated into four subcellular fractions by differential centrifugation. The mixture was first centrifuged at $1000 \mathrm{rpm}$ for $20 \mathrm{~min}$, and the deposition was sampled as a cell wall fraction $\left(\mathrm{F}_{\mathrm{CW}}\right)$ containing the cell wall and cell wall debris. Then, the supernatant solution was centrifuged at $3500 \mathrm{rpm}$ for $20 \mathrm{~min}$ to obtain a deposit that was treated as the organelle fraction $\left(\mathrm{F}_{\mathrm{O}}\right)$ (excluding the vacuole). To isolate the cell membrane fraction, the supernatant was further centrifuged again at $10000 \mathrm{rpm}$ for 20 min. The resulting supernatant was the soluble fraction $\left(\mathrm{F}_{\mathrm{S}}\right)$ containing vacuolar solution and cytoplasmic solution, and the precipitate was denoted the cell membrane fraction $\left(\mathrm{F}_{\mathrm{CM}}\right)$. These four fractions used the digestion and detection methods outlined in the previous section.

\subsection{Determination of rutin, cysteine, glutathione and phytochelatins}

Sneller FE (2000) method was used to determine nonprotein sulfhydryl compounds (cysteine, GSH and PCs). A $0.1 \mathrm{~g}$ fresh plant sample with trifluoroacetic acid $(0.1 \%, 2 \mathrm{~mL})$ was ground into a homogenate.

Then, the sample was centrifuged $\left(4^{\circ} \mathrm{C}, 10000 \mathrm{rpm}, 10 \mathrm{~min}\right)$ after ultrasonic treatment in an ice bath for $30 \mathrm{~min}$. Standard solutions of five sulfhydryl compounds $\left(0.2 \mathrm{mg} \cdot \mathrm{mL}^{-1}\right)$ were prepared with $0.1 \%$ trifluoroacetic acid and diluted to $1.25,2.5,5,10$, and $20 \mathrm{ng} \cdot \mu \mathrm{L}^{-1}$. The procedure of precolumn derivatization of samples and standard series was as follows: 4-hydroxyerhylpiperazine-1propanesulfonic acid $(0.2 \mathrm{M}, 450 \mu \mathrm{L})$ and monobromobimane $(25 \mathrm{mM}, 10 \mu \mathrm{L})$ were added to $250 \mu \mathrm{L}$ of supernatant and reacted in a $45{ }^{\circ} \mathrm{C}$ water bath for $30 \mathrm{~min}$. Methanesulfonic acid $(1 \mathrm{mM}, 300 \mu \mathrm{L})$ was 
added to terminate the reaction. The mixture was filtered through a $0.45 \mu \mathrm{m}$ filter membrane and stored at $4{ }^{\circ} \mathrm{C}$. LC-20 high-performance liquid chromatography was used to determine the contents of cysteine, GSH and PCs.

\subsection{Data acquisition and statistical analysis}

The bioconcentration factor $(\mathrm{BCF})$ is described as the ability of plants to accumulate elements from the substrate. Phytoextraction rate (PER) is broadly defined as the efficiency of the extraction of HMs from soil to plants and are associated with BCFs, plant biomass and soil physics and chemical characteristics. BCF and PER can be calculated by the following equations:

$$
\begin{gathered}
\mathrm{BCF}=\frac{\text { Metal conc. }(\text { plant part) }}{\text { Metal conc. }(\text { soil })} \\
\mathrm{PER}=\frac{\text { Metal conc. }(\text { plant }) \times \text { plants biomass }}{\text { Metal conc. }(\text { soil }) \times \text { soil mass }} \times 100 \%
\end{gathered}
$$

Collection and aggregation of raw data was conducted using EXCEL, and figures were generated with GRAPHPAD PRISM8 and HIPLOT (www.hiplot.com). All data were statistically analyzed using SPSS 24, and significant differences between variables were determined using one-way analysis with the least significant difference (LSD) post hoc test. Differences were statistically significant when $p<0.05$. 


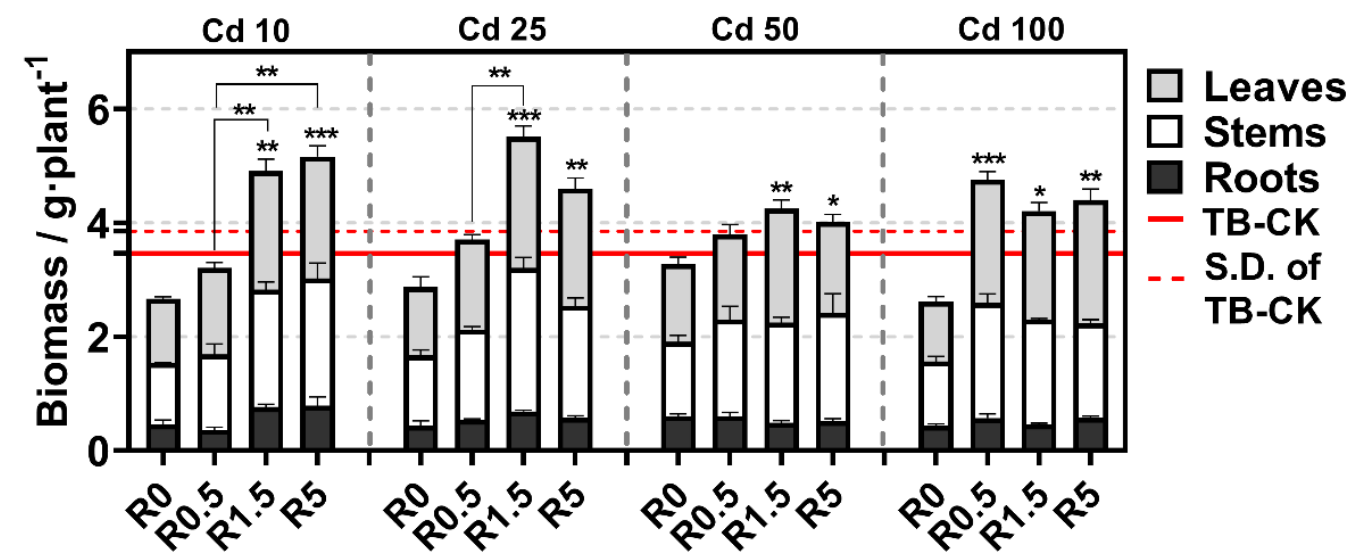

Fig. 1 Cumulative Histogram of biomass under different $\mathrm{Cd}$ conditions and rutin treatments in $A$.

hypochondriacus. The red line of TB-CK represents the total biomass of original control group without Cd

stress and rutin addition. The red dotted line represents the S.D. of TB-CK. The total biomass in the histogram

represents the sum of the biomass of roots, stems and leaves. Asterisks indicate significant differences: $P<$

$0.05(*), P<0.01(* *), P<0.001(* * *)$. Each value represents the mean \pm S.D. of three independent experiments.

Growth characteristics are significant indicators used for phytoremediation evaluation. Plant phenotyping

was performed to determine the effect of exogenous rutin on A. hypochondriacus. Fig. 1 displays an overview of changes in the dried biomass of $A$. hypochondriacus under different Cd stress and rutin treatment levels. What is striking about the biomass data in Fig. 1 is that exogenous rutin can increase the total biomass in all experimental groups in comparison to the nonrutin control groups under all $\mathrm{Cd}$ conditions. Notably, in the R1.5 and R5 treatments under 10 and $25 \mathrm{mg} \cdot \mathrm{kg}^{-1} \mathrm{Cd}$ stress, $A$. 
201

202

203

204

205

206

207

208

209

210

211

biomass was significantly increased by $83.79 \%$ and $93.48 \%$ and $91.98 \%$ and $60.27 \%$ compared with the R0 treatment. Under 10 and $25 \mathrm{mg} \cdot \mathrm{kg}^{-1} \mathrm{Cd}$ conditions, the biomass of roots, stems and leaves increased synergistically, resulting in a distinct increase in total biomass. However, under higher Cd conditions (50 and $100 \mathrm{mg} \cdot \mathrm{kg}^{-1}$ ), the biomass of roots tended to stabilize, and the accretion of total biomass mainly relied on the stems and leaves. It was noted that almost no conspicuous toxicity symptoms of Cd were found in the biomass accumulation of $A$. hypochondriacus with exogenous rutin application. Furthermore, the biological dry matter in the $10,25,50$, and $100 \mathrm{mg} \cdot \mathrm{kg}^{-1} \mathrm{Cd}$ treatments with rutin spray was $1.41-$ $1.49,1.07-1.59,1.10-1.23$, and 1.22-1.36 times higher than in the non-Cd-rutin control group, respectively. For maximal biomass results in this study, a higher concentration of rutin spraying was optimum under medium-low Cd stress $\left(10,25\right.$, and $50 \mathrm{mg} \cdot \mathrm{kg}^{-1} \mathrm{Cd}$ application), while under higher $\mathrm{Cd}$ stress $\left(100 \mathrm{mg} \cdot \mathrm{kg}^{-1}\right)$, relatively low rutin application was sufficient. 
(a)

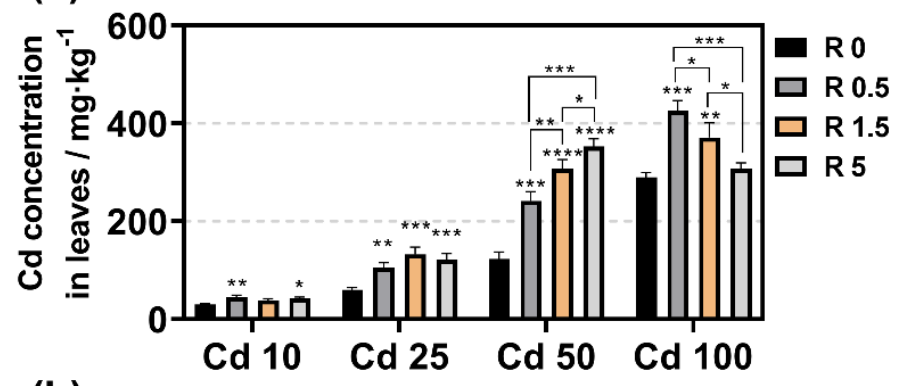

(b)

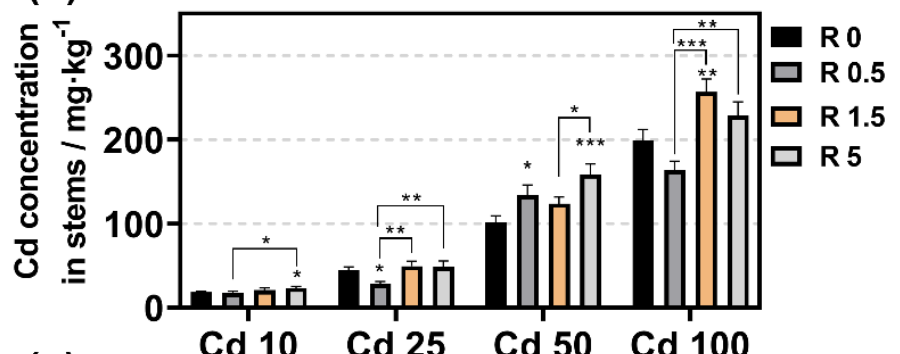

(c)
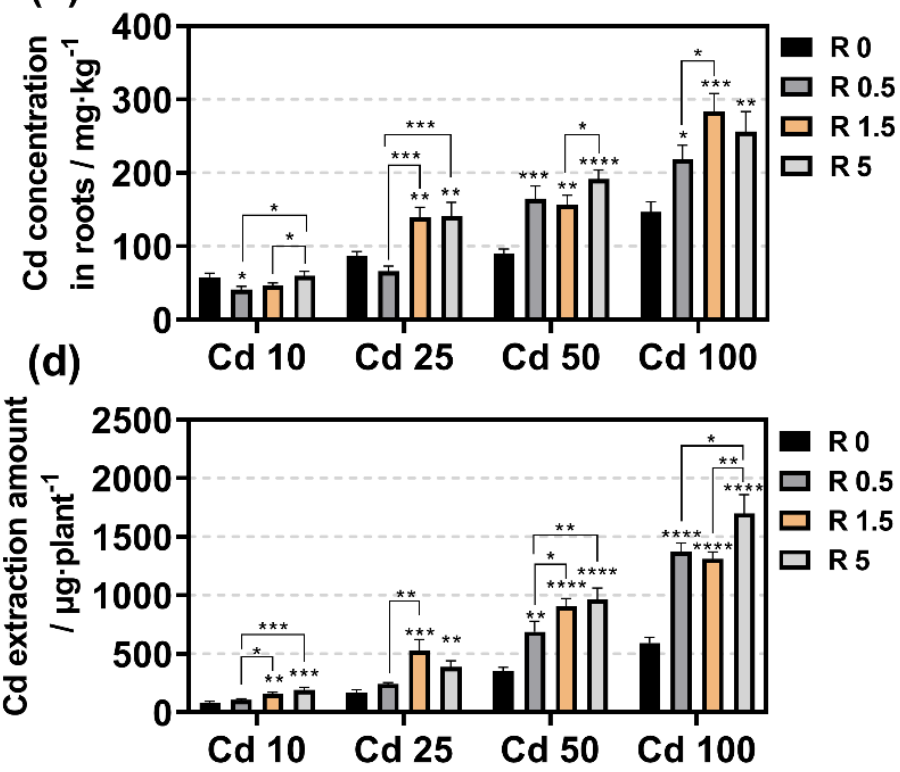

214 Fig. 2 Cd concentration in roots, stems, and leaves and Cd extraction amount of A. hypochondriacus under

215 various $\mathrm{Cd}$ conditions and rutin treatments. (a) Cd concentration in leaves, (b) Cd concentration in stems, (c)

216 Cd concentration in roots, (d) total Cd extraction amount of whole plant calculated by Cd concentration and

217 biomass of Amaranthus hypochondriacus. Each value represents the mean \pm S.D. of three independent 
experiments.

The Cd concentrations in roots, stems, and leaves were significantly changed with the application of rutin. According to Fig. 2 (a), the $\mathrm{Cd}$ concentration in leaves increased visibly under all $\mathrm{Cd}$ conditions under each rutin treatment. Under lower $\mathrm{Cd}$ stress $(\mathrm{Cd} 10)$, different rutin concentrations ( $\mathrm{R} 0.5, \mathrm{R} 1.5$, and $\mathrm{R}$ 5) did not cause a dose-dependent effect on $\mathrm{Cd}$ accumulation in the leaves of $A$. hypochondriacus. However, a significant difference between the rutin groups and the nonrutin groups was evident; the values of the rutin treatments were $1.45,1.26$, and 1.39 times higher than those of the R0 treatment. Under medium $\mathrm{Cd}$ stress $\left(25\right.$ and $\left.50 \mathrm{mg} \cdot \mathrm{kg}^{-1}\right)$, a dose-dependent effect of rutin appeared. The $\mathrm{Cd}$ concentrations in leaves under $25 \mathrm{mg} \cdot \mathrm{kg}^{-1} \mathrm{Cd}$ condition were $105.76,132.96$, and $121.02 \mathrm{mg} \cdot \mathrm{kg}^{-1}$ in $\mathrm{R} 0.5$, R1.5, and R5 groups, respectively, and 1.76-2.22 times higher than in the R0 group. Under $50 \mathrm{mg} \cdot \mathrm{kg}^{-1}$ Cd application, with increasing rutin addition, the $\mathrm{Cd}$ concentration in leaves showed an increasing trend and peaked in the R5 group, which was 2.88 times higher than that in the R0 group, exhibiting a terrific Cd uptake-promoting effect of rutin. Nevertheless, under $100 \mathrm{mg} \cdot \mathrm{kg}^{-1} \mathrm{Cd}$ application, relatively low rutin application caused higher $\mathrm{Cd}$ accumulation in leaves. For stems of A. hypochondriacus (Fig. 2 (b)), the $\mathrm{Cd}$ concentration showed no dramatic improvement in all rutin treatments under relatively low $\mathrm{Cd}$ conditions (10 and $25 \mathrm{mg} \cdot \mathrm{kg}^{-1}$ ). An increase in $\mathrm{Cd}$ concentration was observed under relatively high $\mathrm{Cd}$ conditions (50 and $100 \mathrm{mg} \cdot \mathrm{kg}^{-1}$ ) in all rutin treatments except in the $\mathrm{Cd} 100-\mathrm{R} 0.5$ group. The maximal Cd concentrations were $1.56(\mathrm{Cd} 50-\mathrm{R} 5)$ and $1.29(\mathrm{Cd} 100-\mathrm{R} 1.5)$ times higher than those in the R0 group. As shown in Fig. 2 (c), only the R1.5 and R5 treatments under $25 \mathrm{mg} \cdot \mathrm{kg}^{-1} \mathrm{Cd}$ application reported significantly higher root $\mathrm{Cd}$ concentrations than the $\mathrm{R} 0$ group among all conditions under relatively low 
Cd stress (10 and $\left.25 \mathrm{mg} \cdot \mathrm{kg}^{-1}\right)$. Under relatively high Cd stress (50 and $\left.100 \mathrm{mg} \cdot \mathrm{kg}^{-1}\right)$, the rutin treatment groups still had a higher root $\mathrm{Cd}$ concentration.

\subsection{Cd extraction amount, BCF, and PER}

For HM-contaminated soil, Cd extraction of plants calculated by biomass and Cd concentration are critical evaluation indices for phytoremediation effects. Since both biomass and Cd concentration were affected by rutin, the alteration of $\mathrm{Cd}$ extraction amount was also obvious under the same Cd stress with different rutin treatments. In Fig. 2 (d), there was a clear trend that in all the rutin treatment groups, the Cd extraction amount changed greatly. The maximal values were 189.82, 526.67, 963.22, and 1699.09 $\mu \mathrm{g} \cdot$ plant $^{-1}$ under $10,25,50$, and $100 \mathrm{mg} \cdot \mathrm{kg}^{-1} \mathrm{Cd}$ conditions, respectively, which were $2.35,3.19,2.72$, and 2.86 times higher than that in the $\mathrm{R} 0$ treatment.

Table 1 Effect of rutin on BCF, and PER of A. hypochondriacus under various Cd conditions

\begin{tabular}{|c|c|c|c|c|c|}
\hline & & $\mathrm{Cd} 10$ & $\mathrm{Cd} 25$ & $\mathrm{Cd} 50$ & $\mathrm{Cd} 100$ \\
\hline \multirow{4}{*}{$\mathrm{BCF}$} & R 0 & $3.02 \pm 0.14 \mathrm{~b}$ & $2.29 \pm 0.16 \mathrm{~b}$ & $2.16 \pm 0.11 \mathrm{c}$ & $2.26 \pm 0.14 \mathrm{c}$ \\
\hline & R 0.5 & $3.29 \pm 0.09 \mathrm{ab}$ & $2.62 \pm 0.10 \mathrm{ab}$ & $3.62 \pm 0.09 \mathrm{~b}$ & $2.88 \pm 0.18 b c$ \\
\hline & R 1.5 & $3.23 \pm 0.13 \mathrm{ab}$ & $3.82 \pm 0.23 \mathrm{a}$ & $4.27 \pm 0.07 \mathrm{ab}$ & $3.12 \pm 0.09 \mathrm{~b}$ \\
\hline & R 5 & $3.68 \pm 0.26 \mathrm{a}$ & $3.36 \pm 0.15 b$ & $4.79 \pm 0.10 \mathrm{a}$ & $3.86 \pm 0.16 \mathrm{a}$ \\
\hline \multirow{4}{*}{ PER (\%) } & R 0 & $0.07 \pm 0.01 \mathrm{~b}$ & $0.05 \pm 0.01 \mathrm{~b}$ & $0.06 \pm 0.01 \mathrm{~b}$ & $0.05 \pm 0.01 \mathrm{~b}$ \\
\hline & R 0.5 & $0.09 \pm 0.01 \mathrm{~b}$ & $0.08 \pm 0.01 \mathrm{~b}$ & $0.11 \pm 0.01 \mathrm{ab}$ & $0.11 \pm 0.02 \mathrm{ab}$ \\
\hline & R 1.5 & $0.13 \pm 0.02 \mathrm{ab}$ & $0.18 \pm 0.02 \mathrm{a}$ & $0.15 \pm 0.02 \mathrm{a}$ & $0.11 \pm 0.01 \mathrm{ab}$ \\
\hline & R 5 & $0.16 \pm 0.01 \mathrm{a}$ & $0.13 \pm 0.01 \mathrm{ab}$ & $0.16 \pm 0.02 \mathrm{a}$ & $0.14 \pm 0.01 \mathrm{a}$ \\
\hline
\end{tabular}

The results of the BCF and PER are summarized in Table 1. Rutin application at each concentration (R0.5, R1.5, and R5) increased the BCF of A. hypochondriacus for the treatments with all Cd stresses. Especially in the R5 group, the BCF varied from 3.678, 3.366, 4.798, and 3.862 and was 1.46-2.22 times 
(a)

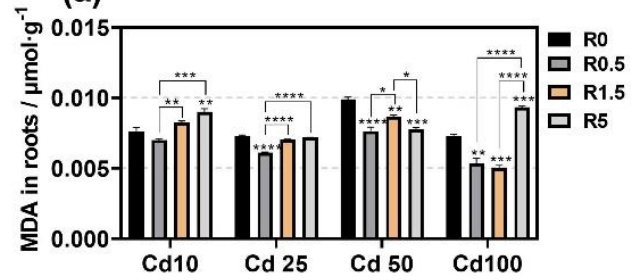

(c)

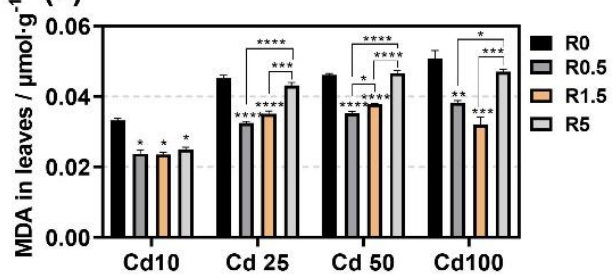

(e)

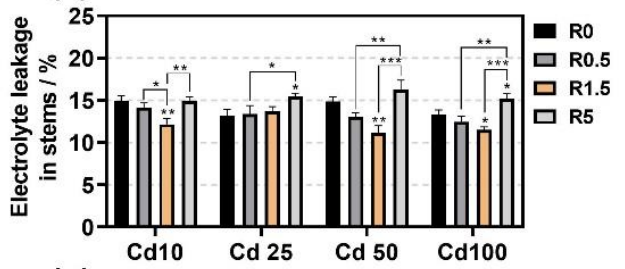

(g)
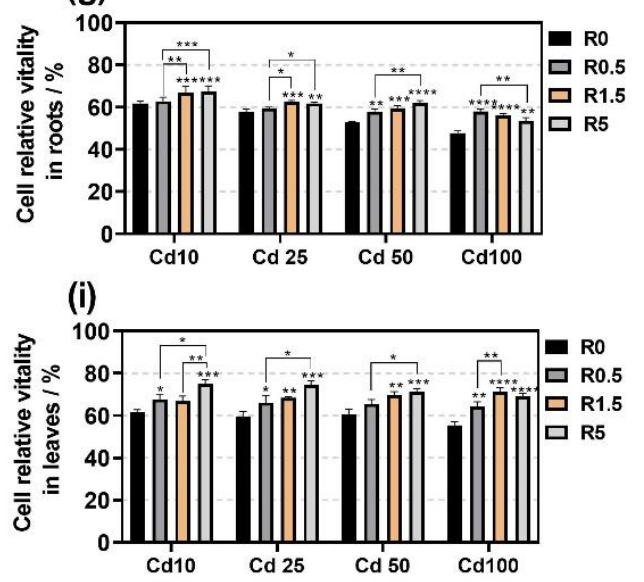

(b)

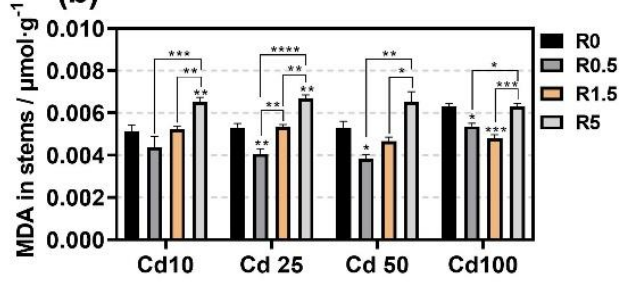

(d)

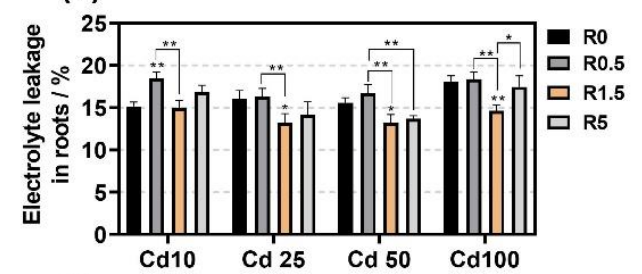

(f)

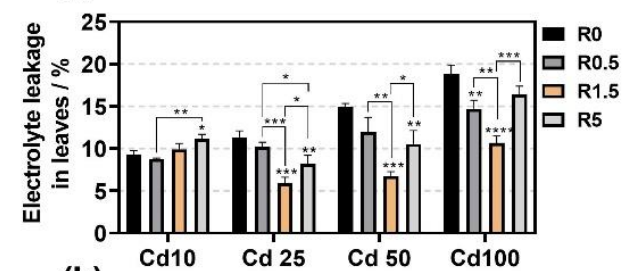

(h)

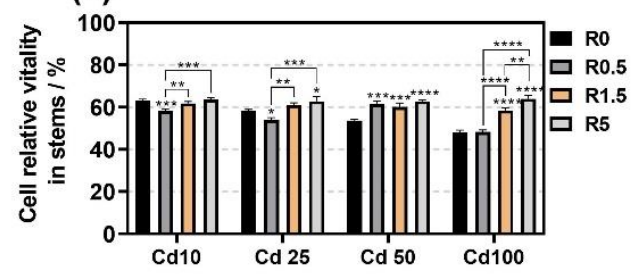

Fig. 3 Changing MDA, EL, and CRV in A. hypochondriacus under various Cd conditions and rutin treatments. 
MDA, EL, and CRV represent malonaldehyde, electrolyte leakage, and cell relative vitality. (a) MDA concentration in roots, (b) MDA concentration in stems, (c) MDA concentration in leaves, (d) EL in roots, (e) EL in stems, (f) EL in leaves, (g) CRV in roots, (h) CRV in stems, (i) CRV in leaves. Asterisks indicate significant differences: $\mathrm{P}<0.05(*), \mathrm{P}<0.01(* *), \mathrm{P}<0.001(* * *), \mathrm{P}<0.0001(* * * *)$. Each value represents the mean \pm S.D. of three independent experiments.

MDA, EL and CRV were measured to evaluate the oxidative damage of membrane lipids in response to rutin application under Cd stress. The MDA content in three tissue parts of $A$. hypochondriacus is shown in Fig. 3 (a)-(c). The MDA content in roots and stems decreased sharply by $53.97 \%$ and $48.26 \%$ compared to that in the R0 group, respectively, in the R0.5 treatment under low Cd stress $\left(10 \mathrm{mg} \cdot \mathrm{kg}^{-1}\right)$, and the MDA content in the R1.5 and R5 groups was still lower than that in the R0 group. Under high Cd stress $\left(100 \mathrm{mg} \cdot \mathrm{kg}^{-1}\right)$, with the exception of stems in the R5 group, all experimental groups presented a marked reduction in the MDA content of roots and stems. These decreasing trends occurred in leaves as well. As the rutin concentration increased, the MDA content in leaves showed a gradual decreasing trend under both high and low Cd stress levels, which declined by $19.04 \%, 21.43 \%$, and $41.86 \%$ in the R0.5, R1.5 and R5 treatments under $10 \mathrm{mg} \cdot \mathrm{kg}^{-1} \mathrm{Cd}$ conditions, respectively, and $13.49 \%, 17.31 \%$, and $14.28 \%$ under $100 \mathrm{mg} \cdot \mathrm{kg}^{-1} \mathrm{Cd}$ conditions, respectively. Fig. 3 (d)-(f) shows that there was an alteration in EL with rutin intervention. In relation to that in the R0 group, EL in the roots and stems of A. hypochondriacus was decreased by $14.15 \%$ and $22.73 \%$ in the R 1.5 treatment, respectively. In terms of leaves, the EL dropped by $7.12 \%, 20.05 \%$, and $8.36 \%$ in the R0.5, R1.5 and R5 groups compared to the R0 group under 10 $\mathrm{mg} \cdot \mathrm{kg}^{-1} \mathrm{Cd}$ conditions, respectively, and $6.12 \%, 20.73 \%$, and $7.53 \%$ under $100 \mathrm{mg} \cdot \mathrm{kg}^{-1} \mathrm{Cd}_{\text {conditions, }}$ respectively. The CRV in the rutin treatments was higher than or equal to that in the control group (R0) 

higher than that of the control. Furthermore, MDA, EL, and CRV were significantly affected by rutin, which changed the physiological parameters of the plants. 

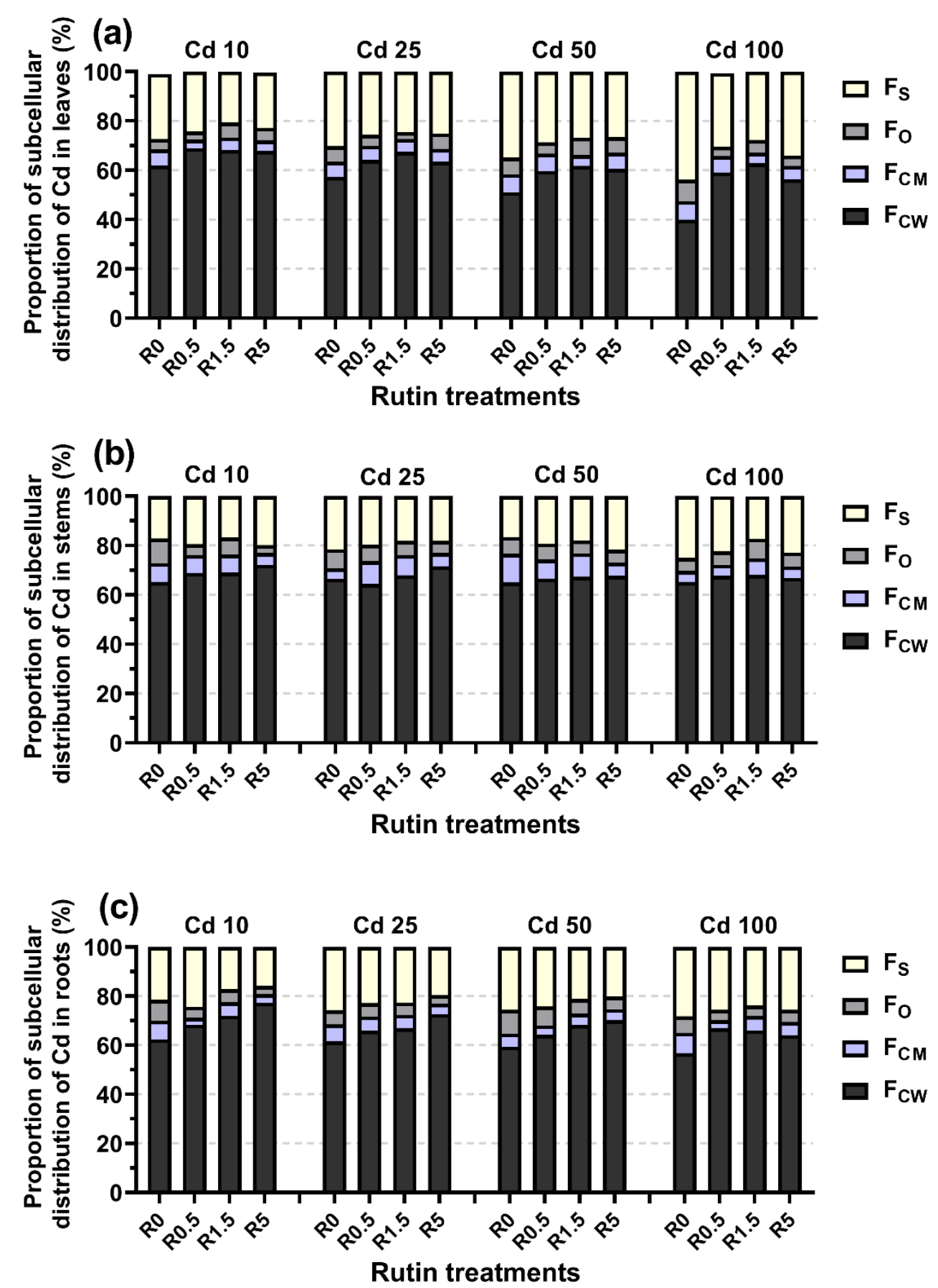

Fig. 4 Proportion of subcellular distribution of $\mathrm{Cd}$ in leaves, stems, and roots of $A$. hypochondriacus under

various $C d$ conditions and rutin treatments. $F_{S}, F_{O}, F_{C M}$, and $F_{C W}$ represent cell wall fraction, organelles 
Cd in roots.

The proportion of $\mathrm{Cd}$ in the subcellular fractions of $A$. hypochondriacus in roots, stems and leaves was in the order of cell wall fraction $\left(\mathrm{F}_{\mathrm{CW}}\right)>$ soluble fraction $\left(\mathrm{F}_{\mathrm{S}}\right)>$ organelle fraction $\left(\mathrm{F}_{\mathrm{O}}\right) \approx$ cell membrane fraction $\left(\mathrm{F}_{\mathrm{CM}}\right)$. Interestingly, the Cd proportion of $\mathrm{F}_{\mathrm{CW}}$ in leaves (Fig. 4 (a)) increased considerably under high Cd stress $\left(100 \mathrm{mg} \cdot \mathrm{kg}^{-1}\right)$ with rutin application, which was $62.44 \%, 59.49 \%$, and $56.34 \%$ in the R0.5, R1.5 and R5 groups, respectively, compared to the R0 group value of $30.50 \%$. Nevertheless, under low Cd stress $\left(10 \mathrm{mg} \cdot \mathrm{kg}^{-1}\right)$, only the R5 group showed an increase in the proportion of $\mathrm{F}_{\mathrm{CW}} \mathrm{Cd}$. A surprising correlation was observed between rutin application and the proportion of $\mathrm{Cd}$ in the $\mathrm{F}_{\mathrm{CM}}$, which showed a slight decreasing trend, and the soluble Cd levels were increased in leaves. The change in the proportion of $\mathrm{Cd}$ in the subcellular fractions under $10 \mathrm{mg} \cdot \mathrm{kg}^{-1} \mathrm{Cd}$ conditions was similar in stems and roots (Fig. 4 (b)-(c)), and the proportion of $\mathrm{Cd}$ in $\mathrm{F}_{\mathrm{CW}}$ in the R0.5 and $\mathrm{R} 5$ groups was higher than in the $\mathrm{R} 0$ group. However, there were no substantial changes in the proportion of $\mathrm{Cd}$ in the $\mathrm{F}_{\mathrm{CW}}$ in stems with or without rutin applied under $100 \mathrm{mg} \cdot \mathrm{kg}^{-1} \mathrm{Cd}$ stress. In contrast, the subcellular distribution of Cd in roots (Fig. 4 (c)) changed with the same rule in accordance with leaves. 
(a)

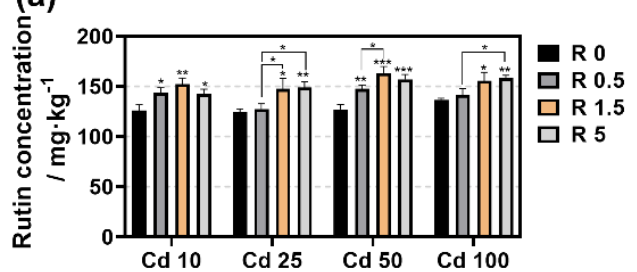

(b)

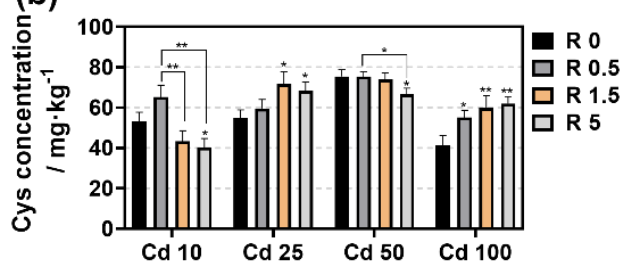

(c)

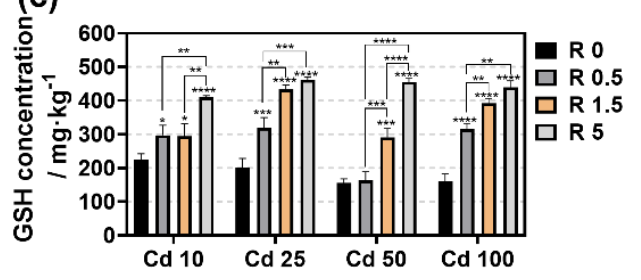

(d)
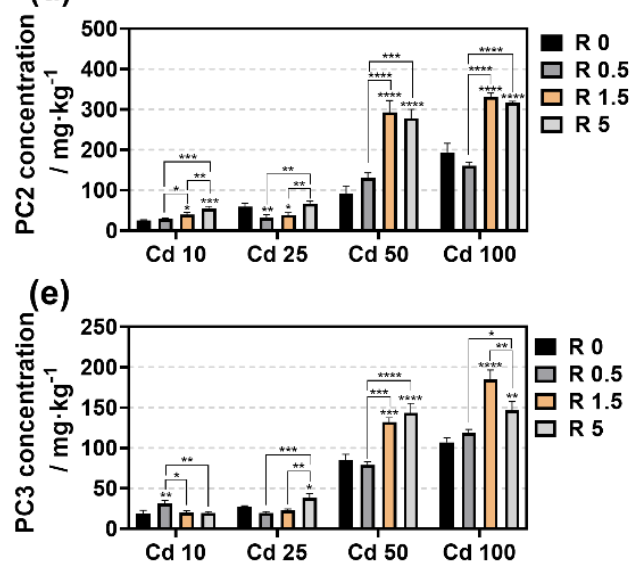

(f)

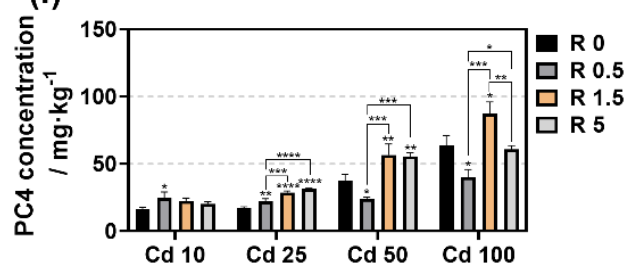

Fig. 5 Changes in rutin, Cys, GSH, PC2, PC3, and PC4 in leaves of $A$. hypochondriacus under various Cd conditions and rutin treatments. Cys and GSH represent cysteine and glutathione, $\mathrm{PC}_{2}, \mathrm{PC}_{3}$, and $\mathrm{PC}_{4}$ are phytochelatins of $\mathrm{PC}_{\mathrm{n}}$ which are oligomers of glutathione. Each value represents the mean \pm S.D. of three independent experiments.

Rutin was only detected in the leaves of $A$. hypochondriacus and revealed no significant alterations in response to Cd stress (Fig. 5 (a)). Under the same level of Cd stress, exogenous rutin caused a rise in endogenous rutin concentration. However, the rutin concentration in the R5 group was not much higher than that in the R1.5 group, and even occasionally, it was lower than that in the R1.5 group. Moreover, there was a surprising outcome in Fig. 5 (b) that the concentration of Cys in the absence or presence of rutin showed no inductive improvement, but the average level of Cys varied among the different $\mathrm{Cd}$ 
groups. The maximal level of Cys was found under $50 \mathrm{mg} \cdot \mathrm{kg}^{-1} \mathrm{Cd}$ conditions, with no observed improvement with rutin application. The Cys levels in the 10 and $100 \mathrm{mg} \cdot \mathrm{kg}^{-1} \mathrm{Cd}$ groups showed very different changes with rutin intervention.

The observed result was also somewhat counterintuitive: A. hypochondriacus cultivated solely with $\mathrm{Cd}$ displayed a declining trend in GSH concentration with increasing Cd stress (Fig. 5 (c)). However, the concentration of GSH increased drastically with the application of rutin, especially in the R5 group, which was $1.82,2.31,2.94$, and 2.74 times higher than that in the R0 treatment under 10, 25, 50, and 100 $\mathrm{mg} \cdot \mathrm{kg}^{-1} \mathrm{Cd}$ conditions, respectively. For PCs (Fig. 5 (d)-(f)), a high level of Cd exposure (50 and 100 $\mathrm{mg} \cdot \mathrm{kg}^{-1}$ ) caused the accumulation of $\mathrm{PC}_{2}, \mathrm{PC}_{3}$, and $\mathrm{PC}_{4}$. The concentrations of $\mathrm{PC}_{2}, \mathrm{PC}_{3}$, and $\mathrm{PC}_{4}$ reached their peak values in the $\mathrm{R} 1.5$ group under $100 \mathrm{mg} \cdot \mathrm{kg}^{-1} \mathrm{Cd}$ conditions. Under relatively low Cd stress (10 and $25 \mathrm{mg} \cdot \mathrm{kg}^{-1}$ ), the PCs showed relatively low response variation levels. Under $10 \mathrm{mg} \cdot \mathrm{kg}^{-1} \mathrm{Cd}$ conditions, only $\mathrm{PC}_{2}$ and $\mathrm{PC}_{4}$ in all rutin groups showed an increase, and the change response of $\mathrm{PC}_{3}$ could not be correlated with rutin. Under $25 \mathrm{mg} \cdot \mathrm{kg}^{-1} \mathrm{Cd}$ conditions, an upward trend was only found in $\mathrm{PC}_{4}$ with increasing rutin application.

The concentrations of nonprotein sulfhydryl compounds in roots and stems are shown in Fig. S1 and Fig. S2 Following the addition of rutin, a significant increase $(p<0.05)$ in Cys and GSH was recorded in roots and stems. There was no significant difference in Cys and GSH content under different Cd stress levels, but the addition of rutin significantly changed the balance. For PCs, plants cultivated solely with different Cd levels showed alterations, but the effect of rutin was not significant under the same Cd conditions. However, due to the interaction between Cys, PCs and GSH for chelating Cd, their contributions to Cd accumulation are shown in the next section by statistical methods. 


\subsection{Correlation analysis and multiple regression model}

As shown in Fig. S3, a statistically significant correlation was observed in three clustering groups: Cys and GSH contents and rutin content, PCs content and soil Cd concentration, and Cys and rutin contents and PCs contents. This result indicated that the addition of rutin enhanced the chelation response of PCs to Cd. However, as Cys and GSH are the precursors for the synthesis and conversion of PCs, the importance of $\mathrm{Cd}$, rutin and nonprotein sulfhydryl compounds is unclear. Prediction models for $\mathrm{Cd}$ content in various organs were established to identify the most significant influencing factors for $\mathrm{Cd}$ accumulation.

A stepwise forward multiple regression method was used to predict $\mathrm{Cd}$ accumulation in roots, stems, leaves, and whole plants of $A$. hypochondriacus. The models were as follows:

$$
\begin{gathered}
\mathrm{Cd}_{\mathrm{wp}}=3.652 \mathrm{Cd}_{\text {soil }}+2.067 \mathrm{R}_{\mathrm{en}}-0.047\left(\mathrm{PC}_{2 \mathrm{R}}\right)^{2}-288.584 \\
\mathrm{Cd}_{\mathrm{L}}=17.347\left(\ln \mathrm{PC}_{3 \mathrm{~L}}\right)^{2}-102.74 \\
\mathrm{Cd}_{\mathrm{S}}=1.449 \mathrm{Cd}_{\text {soil }}+0.272 \mathrm{PC}_{2 \mathrm{~L}} \\
\mathrm{Cd}_{\mathrm{R}}=1.076 \mathrm{PC}_{3 \mathrm{~L}}+50.449
\end{gathered}
$$

where $\mathrm{Cd}_{\mathrm{wp}}, \mathrm{Cd}_{\mathrm{L}}, \mathrm{Cd}_{\mathrm{S}}$, and $\mathrm{Cd}_{\mathrm{R}}$ are the concentration of $\mathrm{Cd}$ in whole plant, leaves, stems, and roots, respectively ( $\left.\mathrm{mg} \cdot \mathrm{kg}^{-1} \mathrm{DW}\right) ; \mathrm{Cd}_{\text {soil }}$ is the Cd concentration in soil (designed value, $\mathrm{mg} \cdot \mathrm{kg}^{-1}$ ); $\mathrm{R}_{\mathrm{en}}$ is the endogenous rutin concentration in plants $\left(\mathrm{mg} \cdot \mathrm{kg}^{-1}\right) ; \mathrm{PC}_{2 \mathrm{R}}$ is the $\mathrm{PC}_{2}$ concentration in roots; and $\mathrm{PC}_{2 \mathrm{~L}}$ and $\mathrm{PC}_{3 \mathrm{~L}}$ are the $\mathrm{PC}_{2}$ and $\mathrm{PC}_{3}$ concentration in leaves, respectively, with $p<0.001$ in the T-test of each coefficient. 

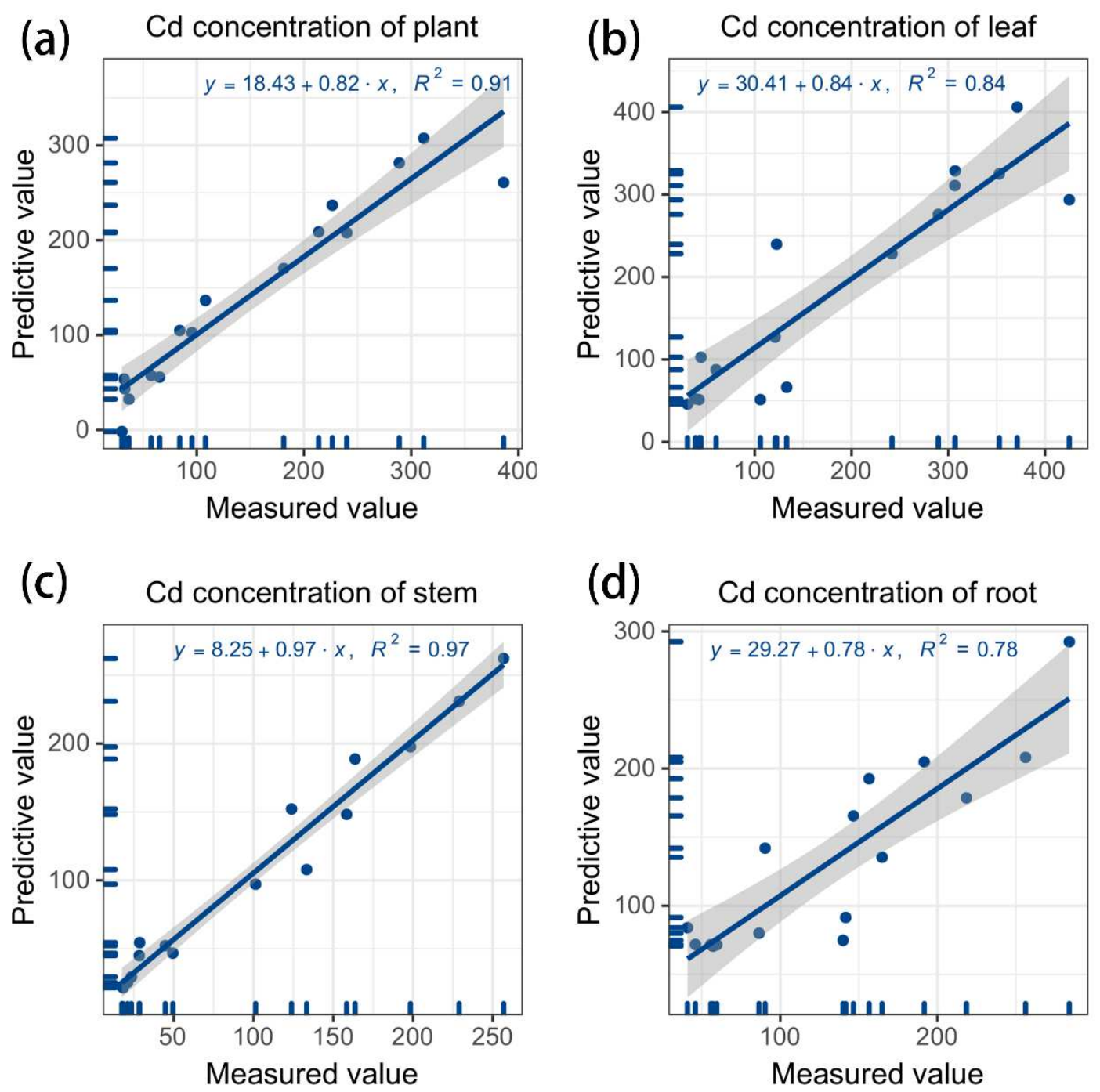

354 Fig. 6 The comparison between the predicted values and measured values of Cd concentration in (a) whole plant, (b) leaf, (c) stem, and (d) root. The solid blue lines represent regression lines, and the gray area represent

$95 \%$ prediction intervals. The regression equations and its $\mathbf{R}^{2}$ are shown in the figure.

The comparison between the predictive value and measured value is displayed in Fig. 6. The model has good fitting, with coefficient of determination $\left(\mathrm{R}^{2}\right)$ values of $0.91,0.84,0.97$, and 0.78 for whole plants, leaves, stems, and roots, respectively. The model of $\mathrm{Cd}_{\mathrm{wp}}$ suggests that $\mathrm{Cd}$ stress in soil, the rutin concentration in plants and the $\mathrm{PC}_{2}$ concentration in roots are crucial to $\mathrm{Cd}$ accumulation in whole plants. 
This observation is also in line with a previous observation that rutin can enhance Cd uptake from soil to

363 plants. The $\mathrm{PC}_{2}$ concentration also indicated that the chelation and fixation of Cd in roots was also the

364 key to increasing Cd accumulation. Additionally, PCs in the leaves play a crucial role in the model of Cd

365 accumulation in leaves, stems, and roots, especially in leaves and roots, and $\mathrm{PC}_{3}$ is primarily responsible

366 for influencing Cd accumulation. The results showed that Cd content in all plant parts was highly correlated with PCs in leaves, which may be due to the application of rutin leading to the transfer of the ability. 


\section{Discussion}

\subsection{Effect of rutin on cell membrane protection and cell tolerance}

Lipid peroxidation is one of the most deleterious effects induced by HM exposure in plants and can directly cause biomembrane deterioration (Yadav 2010). It has been reported that rutin, as a natural flavone derivative, plays a protective role in oxidative stress due to a combination of metal chelation via the ortho-dihydroxy phenolic structure and free radical-scavenging activities (de Matos et al. 2020, Moridani et al. 2003, Rice-Evans et al. 1996) showed that rutin provides cytoprotection to lettuce seedlings through the coordination of mercury and cell membrane protection. In this study, $A$. hypochondriacus cultivated with rutin showed a lower MDA level in roots, stems, and leaves (Fig. 3), which indicated a lower degree of membrane lipoperoxidation. Moreover, plants under advisable rutin treatment displayed less EL in all tissue parts under Cd stress. At the same time, a higher CRV also confirmed that rutin could enhance cell tolerance and alleviate oxidative stress. This phenomenon could be attributed to two factors: one factor is that flavonoids could decrease the fluidity of the membrane hydrophobic core, which could impede the diffusion of free radicals, and the other factor is that rutin could prevent the access of several molecules to the hydrophobic region of the lipid bilayers, which induce oxidative damage to membrane components (Arora et al. 2000, Saija et al. 1995). Thus, flavonoids modify membrane-dependent processes such as free radical-induced membrane lipoperoxidation and interact with penetrating lipid bilayers, causing variation in their structure and fluidity (Sanchez-Gallego et al. 2010).

Since rutin can only be detected in the leaves, it is unknown whether the addition of rutin has a direct effect on the roots and stems. However, due to the increased protective effect of rutin on the cell 
membrane in leaves, the tolerance of photosynthetic plant organs to $\mathrm{Cd}$ is elevated, which promotes this advantage in roots and stems at the same time.

\subsection{Effect of rutin on the chelation and retention of cadmium}

Most plants have high $\mathrm{Cd}$ concentrations in roots due to a restriction effect on the transport of Cd from roots to aboveground parts (Wang et al. 2020). Moreover, hyperaccumulators sequester excess HMs in root vacuoles to mitigate toxic effects in the cytoplasm (Lin \&Aarts 2012). Many studies have emphasized the importance of roots in hyperaccumulator tolerance. However, it seems that through this investigation, PCs in leaves play a more critical role in the neutralization and sequestration of excessive Cd ions, which are key processes in maintaining cellular homeostasis (Yazdi et al. 2019). The GSH concentration in plants relates to upstream and downstream metabolites, and the metabolic process mainly includes synthesis, degradation and conversion (Gao et al. 2020); thus, the concentrations of Cys and PCs may not change in conformity with GSH. In this study, rutin addition under Cd stress in $A$. hypochondriacus caused a significant increase in GSH, which is the foundation of Cd immobilization and compartmentalization in vacuoles (Zhan et al. 2017). This study also demonstrated the correlation between rutin and GSH (Fig. S1). As a precursor of PCs synthesis, GSH affects the chelation and fixation of Cd. Rutin has a strong protective effect against GSH oxidation because the structures produced by its oxidized form do not react well with GSH due to the lack of 3-hydroxyl groups in the flavonoid structure (Lopez-Revuelta et al. 2006). Predictive models were used to define the nonprotein sulfhydryl compounds that were most related to the accumulation of $\mathrm{Cd}$. This method can explain the chelation response more obviously than the analysis of the variation trend of $\mathrm{PCs}$ alone. The results show that $\mathrm{PC}_{2}$ and $\mathrm{PC}_{3}$ in leaves are critical to $\mathrm{Cd}$ accumulation in all tissue parts and that rutin does cause accretion in 
Cd accumulation in whole plants.

It is well established that the subcellular distribution of HMs is significantly altered by exogenous addition, species differences, or planting patterns (Niu et al. 2021, Waheed et al. 2021, Yu et al. 2019). The outcome of the subcellular distribution of $\mathrm{Cd}$ in A. hypochondriacus implies that the compartmentalization effect of $\mathrm{Cd}$ in the cell wall fraction under $\mathrm{Cd}$ stress is the first binding site for $\mathrm{Cd}$ accumulation contributing to $\mathrm{Cd}$ tolerance. Cd immobilization and compartmentalization in the cell wall is a sustainable approach to maintain cell homeostasis under Cd stress within endurance. However, it can be seen in Fig. 4 that when excessive Cd stress occurs, the fixation of the cell wall without rutin application will reach saturation. At this time, PCs in the vacuole and cytoplasm chelate excessive Cd ions to alleviate $\mathrm{Cd}$ toxicity, showing a sharp increase in the soluble $\mathrm{Cd}$ fraction proportion. At this point, the cells reach their maximum $\mathrm{Cd}$ accumulation capacity. $\mathrm{Cd}$ in chloroplasts and mitochondria of cells at higher Cd exposure can cause degradation of the photosynthetic apparatus (Gonçalves et al. 2009, Mwamba et al. 2016). Interestingly, with rutin addition, the Cd proportion in cell walls increased, and the $\mathrm{Cd}$ proportion in organelles decreased. This observation confirms that rutin can affect $\mathrm{Cd}$ accumulation in A. hypochondriacus by altering $\mathrm{Cd}$ subcellular distribution to enhance Cd tolerance.

Vacuolar sequestration and cell wall binding are generally considered to be the main storage methods for Cd in plant cells (Xin et al. 2014). There are different hypotheses about whether PCs-driven Cd retention occurs in vacuoles or cell walls. Several studies have suggested that PCs enhance the cytoplasm and vacuole compartmentalization of $\mathrm{Cd}$ to decrease $\mathrm{Cd}$-induced oxidative damage (Figueira et al. 2014, He et al. 2011, Huang et al. 2021). However, research has also shown that the action of PCs in Cd tolerance is to temporarily bind $\mathrm{Cd}$ in the cytosol, with less contribution to Cd sequestration (Wojas 
et al. 2010). Our subcellular studies show Cd accumulation in roots and leaves with an elevated proportion of $\mathrm{Cd}$ distribution in the cell wall rather than in the solution fraction. This confirms that PCsdriven Cd retention occurs in the cell wall to cope with high $\mathrm{Cd}$ exposure and therefore mitigate $\mathrm{Cd}$ toxicity to the cytoplasm and organelles. To date, it has been shown that flavonoids enhance plant tolerance to Cd and influenced Cd uptake in root cell walls (Li et al. 2015), and Das et al. (2021)) reported that S-induced elevated GSH enables PCs to bind with excess $\mathrm{Cd}$, leading to increased Cd in the cell wall but not in the vacuole. Thus, intracellular mechanisms of elevating Cd tolerance in A. hypochondriacus are related to subcellular partitioning of $\mathrm{Cd}$ and well-coordinated physiological responses.

\subsection{Effect of rutin on phytoextraction and phytoremediation efficiency}

It is now well established from a variety of studies that exposure to excessive $\mathrm{Cd}$ stress could result in a loss of biomass, and plant biomass can be used to estimate the toxic effect of pollutants on plants (Liu et al. 2019). To date, studies have been carried out using exogenous additives to improve plant biomass and phytoextraction to reach a surpassing phytoremediation efficiency. For example, nitrogen fertilizers are most widely used to increase plant biomass and elevate accumulation because of their nutrient supply effect (Eissa \&Roshdy 2018, Giansoldati et al. 2012, Ye et al. 2019). Urea was also used in Cd- and pyrene-contaminated soil remediation and increased the accumulation of soil $\mathrm{Cd}$ and the plant biomass of different parts of willow ( $\mathrm{Li}$ et al. 2021). Many studies have shown that not only traditional fertilizer application but also acids, auxin, and chelate have similar or better phytoremediation properties (Guo et al. 2021, Guo et al. 2019, Lu et al. 2020, Wang et al. 2019). In this work, it was proven that exogenous flavonoids (rutin) also increased phytoextraction by increasing the biomass and Cd accumulation concentration in A. hypochondriacus (Fig. 1 and Fig. 2). However, the mechanism of function of rutin is 
454 different from most of the preceding examples that are based on nutrition and improve the intensity of

455 the antioxidant system. The main functions of rutin are (1) improving cell tolerance under Cd stress by

456 reducing membrane damage and elevating cell vitality and (2) altering the subcellular distribution of $\mathrm{Cd}$

457 and the synthesis of compounds associated with $\mathrm{Cd}$ chelation to drive more $\mathrm{Cd}$ binding to the cell wall.

458 It is therefore evident that exogenous rutin actively functions in eliminating morphological retardation

459 and cell damage in A. hypochondriacus subjected to Cd stress. The increase in PER and BCF (Table 1)

460 of A. hypochondriacus showed that rutin, as a leaf fertilizer additive, can be highly effective in

461 phytoremediation of soil contamination in large fields.

462 
464 The application of rutin showed substantial improvement in biomass, Cd concentration of each tissue part and $\mathrm{Cd}$ phytoextraction under $\mathrm{Cd}$ stress of $A$. hypochondriacus. It is considered according to the actual $\mathrm{Cd}$ concentration of Cd-contaminated soil, foliar application of rutin on the concentration of 1.5 $\mathrm{mg} \cdot \mathrm{kg}^{-1}$ at the branching stage of $A$. hypochondriacus is enough to achieve the highest Cd phytoextraction amount. Furthermore, the underlying mechanisms responsible for this change were explored. Rutin maintains and preserves intracellular homeostasis by altering the permeability of cell membranes to alleviate the stress damage caused by Cd. Rutin also significantly affected the subcellular distribution of each tissue part and whole plant by stepwise forward multiple regression. The soil Cd concentration, rutin concentration and root $\mathrm{PC}_{2}$ matched the amount of $\mathrm{Cd}$ in whole plants well. These models achieve higher Cd phytoextraction amount. Furthermore, these findings provide insights into a less costly way to improve the low efficiency of phytoremediation. 


\section{Reference}

Arora A, Byrem TM, Nair MG, Strasburg GM (2000): Modulation of Liposomal Membrane Fluidity by Flavonoids and Isoflavonoids. Archives of Biochemistry and Biophysics 373, 102-109

Cao F, Cai Y, Liu L, Zhang M, He X, Zhang G, Wu F (2014): Differences in photosynthesis, yield and grain cadmium accumulation as affected by exogenous cadmium and glutathione in the two rice genotypes. Plant Growth Regulation 75, 715-723

Chaurasia N, Mishra Y, Rai LC (2008): Cloning expression and analysis of phytochelatin synthase (pcs) gene from Anabaena sp. PCC 7120 offering multiple stress tolerance in Escherichia coli. Biochem Biophys Res Commun 376, 225-30

Das U, Rahman MA, Ela EJ, Lee KW, Kabir AH (2021): Sulfur triggers glutathione and phytochelatin accumulation causing excess $\mathrm{Cd}$ bound to the cell wall of roots in alleviating Cd-toxicity in alfalfa. Chemosphere 262, 128361

de Matos YMLS, Vasconcelos DLM, Barreto ACH, Rocha JE, Neto JB, Campina FF, de A. M. Guedes TT, Sousa AK, Teixeira RNP, Alvarez-Pizarro JC, Coutinho HDM, da Silva JH (2020): Reduction of the phytotoxic effect of mercury chloride by rutin and evaluation of interactions by vibrational spectroscopy (Raman and FTIR). Vibrational Spectroscopy 109

Dong W, Chen D, Chen Z, Sun H, Xu Z (2021): Antioxidant capacity differences between the major flavonoids in cherry (Prunus pseudocerasus) in vitro and in vivo models. Lwt 141

Eissa MA, Roshdy NMK (2018): Nitrogen fertilization: Effect on Cd-phytoextraction by the halophytic plant quail bush [Atriplex lentiformis (Torr.) S. Wats]. South African Journal of Botany 115, 126-131

Figueira E, Freitas R, Guasch H, Almeida SF (2014): Efficiency of cadmium chelation by phytochelatins in Nitzschia palea (Kutzing) W. Smith. Ecotoxicology 23, 285-92

Gao Y, Li H, Song Y, Zhang F, Lu Y, Peng F, Yang Z (2020): Decisive Enzymes and Prediction Models for the Glutathione Content in Spinach (Spinacia oleracea L.) Exposed to Cadmium. J Agric Food Chem 68, 11855-11862

Ghasemi R, Sharifi R, Ghaderian SM (2020): Studying the roles of calcium and magnesium in cell death in the serpentine native plant Alyssum inflatum NYARADY through cell suspension culture technique. Plant Physiol Biochem 151, 362-368

Giansoldati V, Tassi E, Morelli E, Gabellieri E, Pedron F, Barbafieri M (2012): Nitrogen fertilizer improves boron phytoextraction by Brassica juncea grown in contaminated sediments and alleviates plant stress. Chemosphere 87, 1119-25

Gonçalves JF, Nicoloso FT, Becker AG, Pereira LB, Tabaldi LA, Cargnelutti D, de Pelegrin CMG, Dressler VL, da Rocha JBT, Schetinger MRC (2009): Photosynthetic pigments content, $\delta$ aminolevulinic acid dehydratase and acid phosphatase activities and mineral nutrients concentration in cadmium-exposed Cucumis sativus L. Biologia 64, 310-318

Gong G, Qin Y, Huang W, Zhou S, Yang X, Li D (2010): Rutin inhibits hydrogen peroxide-induced apoptosis through regulating reactive oxygen species mediated mitochondrial dysfunction pathway in human umbilical vein endothelial cells. Eur J Pharmacol 628, 27-35

Guo B, Liu C, Lin Y, Li H, Li N, Liu J, Fu Q, Tong W, Yu H (2021): Fruit extracts from Phyllanthus 
emblica accentuate cadmium tolerance and accumulation in Platycladus orientalis: A new natural chelate for phytoextraction. Environ Pollut 280, 116996

Guo D, Ali A, Ren C, Du J, Li R, Lahori AH, Xiao R, Zhang Z, Zhang Z (2019): EDTA and organic acids assisted phytoextraction of $\mathrm{Cd}$ and $\mathrm{Zn}$ from a smelter contaminated soil by potherb mustard (Brassica juncea, Coss) and evaluation of its bioindicators. Ecotoxicol Environ Saf 167, 396403

He J, Qin J, Long L, Ma Y, Li H, Li K, Jiang X, Liu T, Polle A, Liang Z, Luo ZB (2011): Net cadmium flux and accumulation reveal tissue-specific oxidative stress and detoxification in Populus $\mathrm{X}$ canescens. Physiol Plant 143, 50-63

Huang Y, Chen J, Zhang D, Fang B, YangJin T, Zou J, Chen Y, Su N, Cui J (2021): Enhanced vacuole compartmentalization of cadmium in root cells contributes to glutathione-induced reduction of cadmium translocation from roots to shoots in pakchoi (Brassica chinensis L.). Ecotoxicol Environ Saf 208, 111616

Jacquart A, Brayner R, El Hage Chahine JM, Ha-Duong NT (2017): Cd(2+) and Pb(2+) complexation by glutathione and the phytochelatins. Chem Biol Interact 267, 2-10

Li J, Lu H, Liu J, Hong H, Yan C (2015): The influence of flavonoid amendment on the absorption of cadmium in Avicennia marina roots. Ecotoxicol Environ Saf 120, 1-6

Li Y, Xie T, Zha Y, Du W, Yin Y, Guo H (2021): Urea-enhanced phytoremediation of cadmium with willow in pyrene and cadmium contaminated soil. J Hazard Mater 405, 124257

Lin YF, Aarts MG (2012): The molecular mechanism of zinc and cadmium stress response in plants. Cell Mol Life Sci 69, 3187-206

Liu WT, Ni JC, Zhou QX (2013): Uptake of Heavy Metals by Trees: Prospects for Phytoremediation. Materials Science Forum 743-744, 768-781

Liu X, Mao Y, Zhang X, Gu P, Niu Y, Chen X (2019): Effects of PASP/NTA and TS on the phytoremediation of pyrene-nickel contaminated soil by Bidens pilosa L. Chemosphere 237, 124502

Liu Z-Q, Li H-L, Zeng X-J, Lu C, Fu J-Y, Guo L-J, Kimani WM, Yan H-L, He Z-Y, Hao H-Q, Jing H-C (2020): Coupling phytoremediation of cadmium-contaminated soil with safe crop production based on a sorghum farming system. Journal of Cleaner Production 275

Lopez-Revuelta A, Sanchez-Gallego JI, Hernandez-Hernandez A, Sanchez-Yague J, Llanillo M (2006): Membrane cholesterol contents influence the protective effects of quercetin and rutin in erythrocytes damaged by oxidative stress. Chem Biol Interact 161, 79-91

Lu Q, Weng Y, You Y, Xu Q, Li H, Li Y, Liu H, Du S (2020): Inoculation with abscisic acid (ABA)catabolizing bacteria can improve phytoextraction of heavy metal in contaminated soil. Environ Pollut 257, 113497

Moridani MY, Pourahmad J, Bui H, Siraki A, O’Brien PJ (2003): Dietary flavonoid iron complexes as cytoprotective superoxide radical scavengers. Free Radical Biology and Medicine 34, 243-253

Mwamba TM, Li L, Gill RA, Islam F, Nawaz A, Ali B, Farooq MA, Lwalaba JL, Zhou W (2016): Differential subcellular distribution and chemical forms of cadmium and copper in Brassica napus. Ecotoxicol Environ Saf 134P1, 239-249

Niu H, Wang Z, Song J, Long A, Cao M, Luo J (2021): Cadmium subcellular distribution and chemical form in Festuca arundinacea in different intercropping systems during phytoremediation. Chemosphere 276, 130137 
Qin G, Niu Z, Yu J, Li Z, Ma J, Xiang P (2021): Soil heavy metal pollution and food safety in China: Effects, sources and removing technology. Chemosphere 267, 129205

Rice-Evans CA, Miller NJ, Paganga G (1996): Structure-antioxidant activity relationships of flavonoids and phenolic acids. Free Radic Biol Med 20, 933-56

Saija A, Scalese M, Lanza M, Marzullo D, Bonina F, Castelli F (1995): Flavonoids as antioxidant agents: importance of their interaction with biomembranes. Free radical biology \&amp; medicine 19, 481-486

Sanchez-Gallego JI, Lopez-Revuelta A, Sardina JL, Hernandez-Hernandez A, Sanchez-Yague J, Llanillo M (2010): Membrane cholesterol contents modify the protective effects of quercetin and rutin on integrity and cellular viability in oxidized erythrocytes. Free Radic Biol Med 48, 1444-54

Singh S, Dubey V, Meena A, Siddiqui L, Maurya AK, Luqman S (2018): Rutin restricts hydrogen peroxide-induced alterations by up-regulating the redox-system: An in vitro, in vivo and in silico study. Eur J Pharmacol 835, 115-125

Sneller FE vHL, Koevoets PL, Vooijs R, Schat H, Verkleij JA (2000): Derivatization of phytochelatins from Silene vulgaris, induced upon exposure to arsenate and cadmium: comparison of derivatization with Ellman's reagent and monobromobimane. \% J Journal of Agricultural \& Food Chemistry. J Agric Food Chem 48, 4014

Stingu A, Volf I, Popa VI, Gostin I (2012): New approaches concerning the utilization of natural amendments in cadmium phytoremediation. Industrial Crops and Products 35, 53-60

Waheed S, Ahmad R, Irshad M, Khan SA, Mahmood Q, Shahzad M (2021): Ca2SiO4 chemigation reduces cadmium localization in the subcellular leaf fractions of spinach (Spinacia oleracea L.) under cadmium stress. Ecotoxicol Environ Saf 207, 111230

Wang J, Zhao J, Feng S, Zhang J, Gong S, Qiao K, Zhou A (2020): Comparison of cadmium uptake and transcriptional responses in roots reveal key transcripts from high and low-cadmium tolerance ryegrass cultivars. Ecotoxicol Environ Saf 203, 110961

Wang L, Zhang Q, Liao X, Li X, Zheng S, Zhao F (2021): Phytoexclusion of heavy metals using low heavy metal accumulating cultivars: A green technology. J Hazard Mater 413, 125427

Wang R, Sun Y, Huang H, Wang L, Chen J, Shen W (2015): Rutin, A Natural Flavonoid Protects PC12 Cells Against Sodium Nitroprusside-Induced Neurotoxicity Through Activating PI3K/Akt/mTOR and ERK1/2 Pathway. Neurochem Res 40, 1945-53

Wang Y, Meng D, Fei L, Dong Q, Wang Z (2019): A novel phytoextraction strategy based on harvesting the dead leaves: Cadmium distribution and chelator regulations among leaves of tall fescue. Sci Total Environ 650, 3041-3047

Wei S, Li Y, Zhou Q, Srivastava M, Chiu S, Zhan J, Wu Z, Sun T (2010): Effect of fertilizer amendments on phytoremediation of Cd-contaminated soil by a newly discovered hyperaccumulator Solanum nigrum L. J Hazard Mater 176, 269-73

Wojas S, Ruszczynska A, Bulska E, Clemens S, Antosiewicz DM (2010): The role of subcellular distribution of cadmium and phytochelatins in the generation of distinct phenotypes of AtPCS1and CePCS3-expressing tobacco. J Plant Physiol 167, 981-8

Xie M, Chen W, Lai X, Dai H, Sun H, Zhou X, Chen T (2019): Metabolic responses and their correlations with phytochelatins in Amaranthus hypochondriacus under cadmium stress. Environ Pollut 252, $1791-1800$

Xie Y, Luo Y, Sheng M, Peng H, Gu Y, Xu H, Zhao Y (2020): 24-Epibrassinolide combined with heavy 
metal resistant bacteria enhancing phytoextraction of Amaranthus hypochondriacus L. in Cdcontaminated soil. J Hazard Mater 399, 123031

Xin J, Huang B, Dai H, Liu A, Zhou W, Liao K (2014): Characterization of cadmium uptake, translocation, and distribution in young seedlings of two hot pepper cultivars that differ in fruit cadmium concentration. Environ Sci Pollut Res Int 21, 7449-56

Yadav SK (2010): Heavy metals toxicity in plants: An overview on the role of glutathione and phytochelatins in heavy metal stress tolerance of plants. South African Journal of Botany 76, 167-179

Yazdi M, Kolahi M, Mohajel Kazemi E, Goldson Barnaby A (2019): Study of the contamination rate and change in growth features of lettuce (Lactuca sativa Linn.) in response to cadmium and a survey of its phytochelatin synthase gene. Ecotoxicol Environ Saf 180, 295-308

Ye X, Hu H, Li H, Xiong Q, Gao H (2019): Combined nitrogen fertilizer and wheat straw increases the cadmium phytoextraction efficiency of Tagetes patula. Ecotoxicol Environ Saf 170, 210-217

Yu Y, Fu P, Huang Q, Zhang J, Li H (2019): Accumulation, subcellular distribution, and oxidative stress of cadmium in Brassica chinensis supplied with selenite and selenate at different growth stages. Chemosphere 216, 331-340

Yuan H, Zhang Y, Huang S, Yang Y, Gu C (2015): Effects of exogenous glutathione and cysteine on growth, lead accumulation, and tolerance of Iris lactea var. chinensis. Environ Sci Pollut Res Int 22, 2808-16

Zayneb C, Imen RH, Walid K, Grubb CD, Bassem K, Franck V, Hafedh M, Amine E (2017): The phytochelatin synthase gene in date palm (Phoenix dactylifera L.): Phylogeny, evolution and expression. Ecotoxicol Environ Saf 140, 7-17

Zhan F, Li B, Jiang M, Qin L, Wang J, He Y, Li Y (2017): Effects of a root-colonized dark septate endophyte on the glutathione metabolism in maize plants under cadmium stress. Journal of Plant Interactions 12, 421-428 


\section{Supplementary Files}

This is a list of supplementary files associated with this preprint. Click to download.

- SupplementaryInformation.docx 